\title{
階段状水路における空気混入射流の特性に対する レイノルズ数の影響
}

\section{EFFECT OF REYNOLDS NUMBER ON CHARACTERISTICS OF AERATED FLOW IN STEPPED CHANNELS}

\author{
高橋 正行 $^{1} \cdot$ 安田 陽 ${ }^{2} \cdot$ 大津 $^{\text {岩夫 }}{ }^{3}$
}

\author{
Masayuki TAKAHASHI, Youichi YASUDA, and Iwao OHTSU
}

\footnotetext{
${ }^{1}$ 正会員 博(工) 日本大学助手 理工学部土木工学科 (下101-8308 東京都千代田区神田駿河台 1-8) 2 正会員 博(工) 日本大学助教授 理工学部土木工学科 (广101-8308 東京都千代田区神田駿河台 1-8)

3フェロー会員 工博 日本大学教授 理工学部土木工学科 (广101-8308 東京都千代田区神田駿河台 1-8)
}

\begin{abstract}
Stepped channels are effective for dissipating the energy of high-velocity flows on chutes. For hydraulic design of stepped channels, it is important to clarify the effect of Reynolds number on characteristics of skimming flows in stepped channels. This paper presents the effect of Reynolds number on the air-concentration and the mean velocity profiles of skimming flows. The analysis of experimental data reveals that the effect of Reynolds number $R_{e}$ on the air-concentration and the mean velocity profiles is negligible in the range of $4.0 \times 10^{4} \leq R_{e} \leq 3.7 \times 10^{5}$. Also, Froude similarity law of aerated flows in stepped channels has been discussed, and an application to hydraulic design of stepped channels has been explained in accordance with the relation of scale between proto-type and experimental models.
\end{abstract}

Key Words: Scale effect, Reynolds number, stepped channel, aerated flow, skimming flow, Froude similarity law

\section{1.まえがき}

落差を有寸る構造物を流下寸る高速流を減勢させる方法と して階段状水路の利用が有効である. 階段状水路で形成され る流れは空気混入を伴場合が多く(写真 - 1) , この空気混 入射流の水深や流速を求めることは水工設計上重要である.

階段状水路において形成される流況は Skimming flow (図 - 1(a)), Nappe flow (図 - 1(c))および Transition flow (図 - 1(b)) である ${ }^{1), 2)}$.

Boes and Hager は Skimming flow を対象に空気混入率分 布形状の変化について実験的検討を行い,レイノルズ数 $R_{e}\left(R_{e}=q_{w} / v_{\mathrm{w}} ; q_{w}\right.$ は単位幅流量 $\left(q_{w}=Q_{w} / B ; Q_{\mathrm{w}}\right.$ は水のみ の流量; $B$ は水路幅), $v_{w}$ は水の動粘性係数)が $R_{e} \leq 1.0 \times 10^{5}$ の場合に空気混入の分布特性に対してレイノルズ数の影響 があるとしている゙ ${ }^{3)}$ しかしながら， aerated flow 内の空気混 入率の分布特性に対するレイノルズ数 $R_{e}$ の影響を明らかに するためには資料の解析方法に検討の余地がある. また, 階段状水路における空気混入射流 (写真 -1 参照)の aerated flow depth および流速分布に対するレイノルズ数 $R_{e}$ の影響については不明である.

本研究では, Skimming flowの空気混入率の分布, aerated flow depth, および流速分布の実験結果についてフルード

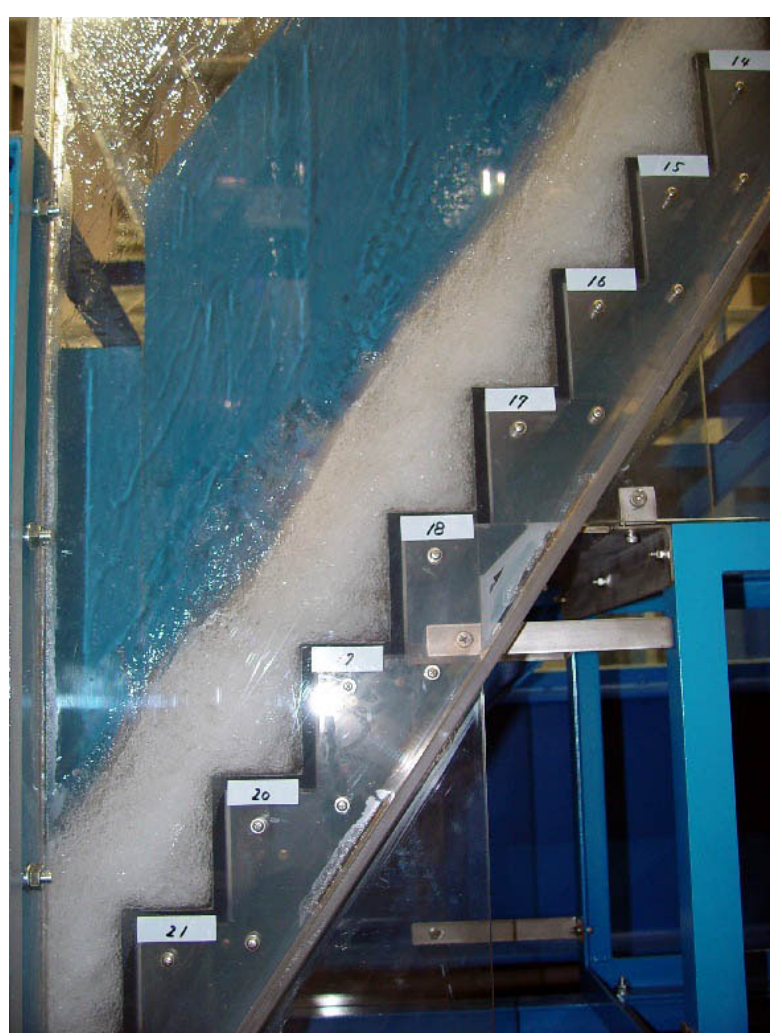

写真 -1 階段状水路の Skimming flow 
a)

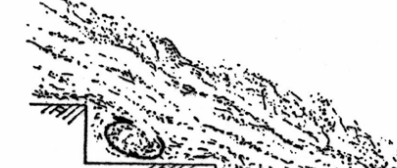

b)

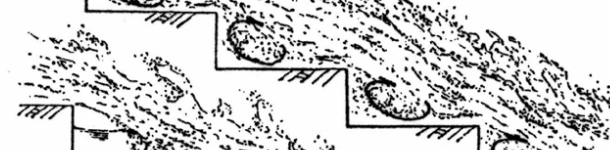

c) $\mathrm{s}$
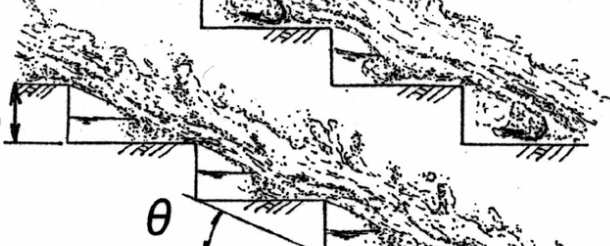

図 - 1 階段状水路の流況

a) Skimming flow, b) Transition flow, c) Nappe flow
表 - 1 実験条件

\begin{tabular}{ccccccc}
\hline & $\begin{array}{c}\theta \\
(\mathrm{deg})\end{array}$ & $\begin{array}{c}S \\
(\mathrm{~cm})\end{array}$ & $\begin{array}{c}H_{\text {dam }} \\
(\mathrm{cm})\end{array}$ & $\begin{array}{c}B \\
(\mathrm{~cm})\end{array}$ & $\begin{array}{c}S / d_{c} \\
R_{e} \\
{\left[\times 10^{4}\right]}\end{array}$ \\
\hline Run 1 & 55 & 10 & 249 & 50 & 1 & 8.2 \\
Run2 & 55 & 5 & 249 & 50 & 1 & 2.9 \\
Run 3 & 55 & 2.5 & 82 & 40 & 1 & 1.3 \\
Run 4 & 55 & 1.25 & 82 & 40 & 1 & 0.4 \\
Run5 & 55 & 2.5 & 153 & 40 & 0.8 & 1.6 \\
Run6 & 55 & 5 & 249 & 50 & 0.5 & 7.8 \\
Run7 & 55 & 2.5 & 249 & 50 & 0.5 & 4.2 \\
Run8 & 55 & 1.25 & 249 & 50 & 0.5 & 1.5 \\
Run9 & 55 & 0.63 & 249 & 50 & 0.5 & 0.5 \\
Run10 & 55 & 2.5 & 249 & 50 & 0.25 & 12 \\
Run11 & 55 & 1.25 & 249 & 50 & 0.25 & 4.3 \\
Run12 & 55 & 0.63 & 249 & 50 & 0.25 & 1.5 \\
\hline
\end{tabular}

$S$ : ステップ高さ, $d_{c}$ : 限界水深 $\left(d_{c}=\left(q_{w}{ }^{2} / g\right)^{1 / 3}\right), q_{w}$ : 単位幅流量, $R_{e}$ : レイノルズ数 $\left(R_{e}=q_{w} / v_{w}\right), \theta:$ 水路傾斜角度, $H_{d a m}$ :ダム高さ
の相似則が適用できるレイノルズ数 $R_{e}$ の範囲を明らかにし た. これによって, 水工設計に必要な模型実験の規模が定 められるようになった.

\section{2.実験方法}

階段状水路における空気混入率の分布特性を明らかにす るため, WES の標準堤頂を有する階段状水路模型を用いて 表 - 1 に示寸条件のもとで実験を行った (図 - 2 参照). 空気混入率 $C[C=$ (空気量) / 空気量十水の量 $)]$ 測定は点 電極型ボイド率計を用い, 検出部を edge section(図 - 3 参 照に設置して行った(採取間隔 $5 \mathrm{~ms}$, 採取時間 $60 \mathrm{sec}$ )。な お,検出部の設置の精度は土 $0.5 \mathrm{~mm}$ 以内である.

\section{3.空気混入率分布に対するレイノルズ数の影響}

擬似等流状態における Skimming flow の aerated flow depth $y_{0.9}$ 内の断面平均された空気混入率 $C_{m}$ は次の関係で 示されるものと考えられる.

$$
C_{m}=F\left(S, \theta, d, V_{w}, \mu_{w}, \rho_{w}, \sigma_{w a}, g\right)
$$

ここに， $S$ はステップ高さ, $\theta$ は水路傾斜角度， $d$ は水のみ に換算をした水深 ${ }^{2,5) \sim 8)}\left(d=\int_{0}^{y_{0.9}}(1-C) d y=\left(1-C_{m}\right) y_{0.9}\right)$, $V_{w}$ は断面平均流速 $\left(V_{w}=q_{w} / d\right), \mu_{w}$ は水の粘性係数, $\rho_{w}$ は水 の密度, $\sigma_{w a}$ は水の表面張力, $g$ は重力加速度であり, $C_{m}$ は次 式で定義されている2,5) 8).

$$
C_{m}=\frac{1}{y_{0.9}} \int_{0}^{y_{0.9}} C d y
$$

なお, $y_{09}$ は $C=0.9$ となる $y(y$ は仮想底面からの垂直座標 (図 -3 参照))である.

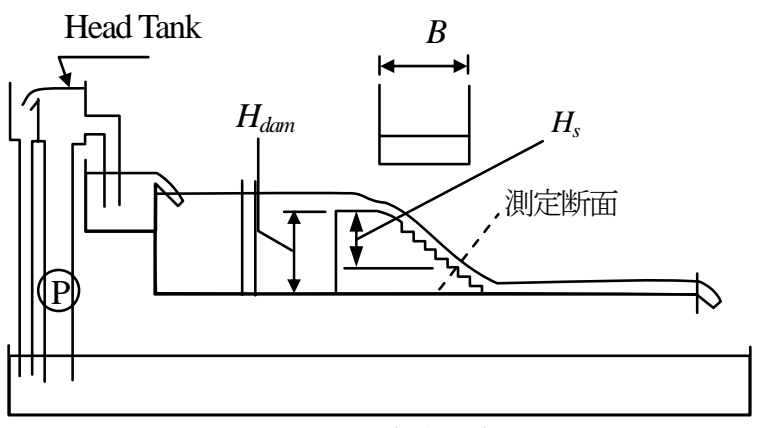

図 -2 実験水路

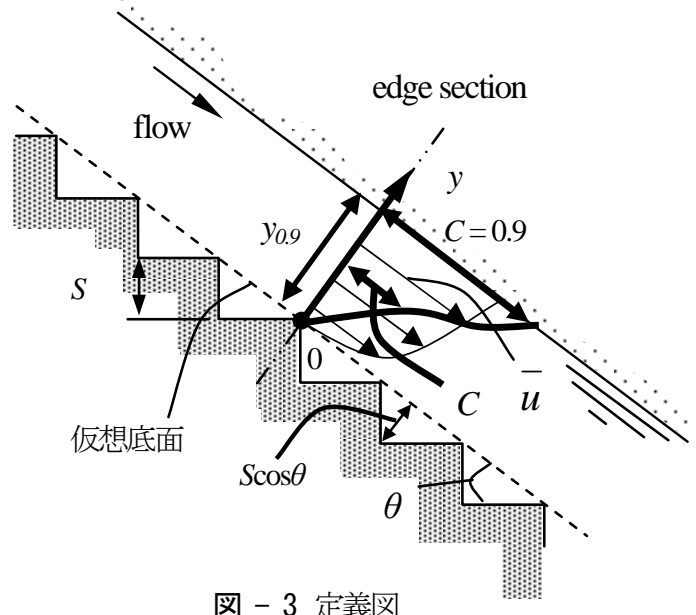

図 -3 定義困

次元解析的考察力ら(1)式の関倸は次のように変換される.

$$
C_{m}=F\left(\frac{S \cos \theta}{d}, R_{e}, F_{r}, W_{e}, \theta\right)
$$

ここに, $R_{e}$ はレイノルズ数 $\left[R_{e}=q_{w} / v_{w} ; v_{w}\right.$ は水の動粘性係数 $]$, $W_{e}$ はウェバー数 $\left[W_{e}=\rho_{w} d V_{W}^{2} / \sigma_{w a} ;\right], \quad F_{r}$ はフルード数 $\left[F_{r}=\right.$ $V_{w} /(g d \cos \theta)^{0.5}$ である.

Skimming flow における aerated flow の内部特性について 検討するためには, aerated flow の代表水深の選定が重要で ある.ここでは, aerated flow depthを $y_{0.9}$ と定め, 連続の式を満 
足するか研かに着目し, その妥当性について検討する.

$0 \leq y \leq y_{0.9}$ の範用で測定された時間平均流速 $\bar{u}$ と空気 混入率 $C$ から単位幅流量 $q_{w}$ ' は次のように求められる2),4).

$$
q_{w}{ }^{\prime}=\int_{0}^{y_{0.9}}(1-C) \bar{u} d y
$$

( 4 )式で求められた単位幅流量 $q_{w}$ ' は水のみの流量の実 測值力ら求めた単位幅流量 $q_{w}\left(q_{w}=Q_{w} / B ; Q_{w}\right.$ は刃型堰を用い て測定された流量)之ほぼ一致する ${ }^{4}$. 寸なおち, 代表水深と して aerated flow depth $y_{09}$ を用いることで連続の式 $\left(q_{w}{ }^{\prime}=q_{w}\right)$ を 満足する. また, $y_{0.9}$ を空気混入射流の代表水深しし, 空気混 入射流の密度 $\rho$ を $\rho=\rho_{w}(1-C)$ として表わすことで, 空気混入 射流のエネルギーと平均流速を算定寸ることができる 5 )。 の. 以 上より，aerated flow depth として $y_{0.9}$ を用いることとする.

擬似等流状態で断面中央部における aerated flow depth $y_{0.9}$ 内の空気混入率 $C$ は ( 2 )式と( 3 )式の関係加次のよう に表示されるものと考えられる.

$$
C=F\left(\frac{y}{y_{0.9}}, \frac{S \cos \theta}{d}, R_{e}, F_{r}, W_{e}, \theta\right)
$$

ウェバー数 $W_{e}$ は liquid parameter $\left.\left(=\rho_{w} \sigma_{w a}^{3} / g \mu_{w}\right)^{7}\right)$ を用い ると次のように示される。

$$
W_{e}=\left(\rho_{w} \sigma_{w a}{ }^{3} / g \mu_{w}\right)\left(F_{r}{ }^{2} R_{e}{ }^{4}\right)^{1 / 6}
$$

階段状水路の場合, 水と空気とが対象となることから, liquid parameter はほぼ一定值を示寸.このことから, ウェバー数は レイノルズ数とフルード数とによって示すことができる.

擬似等流状態の Skimming flow における抵抗係数 $f$ は次 式で定義されている5 .

$$
f=\frac{4 \tau_{0}}{\rho_{w} V_{w}{ }^{2} / 2}=8\left(\frac{d}{d_{c}}\right)^{3} \sin \theta
$$

ここに, $\tau_{0}$ は仮想底面に作用しているせん断灾力 $\left(\tau_{0}=\rho_{n} g d \sin \theta\right)$ である.

フルード数 $F_{r}$ および相対粗度高さ $S \cos \theta / d$ は 7 )式を用 いると次のように表すことができる.

$$
\begin{gathered}
F_{r}=\frac{V_{w}}{\sqrt{g d \cos \theta}}=\left(\frac{d_{c}}{d}\right)^{\frac{3}{2}} \frac{1}{\sqrt{\cos \theta}}=\sqrt{\frac{8 \tan \theta}{f}} \\
\frac{S \cos \theta}{d}=\frac{S}{d_{c}} \frac{d_{c}}{d} \cos \theta=\frac{S}{d_{c}} \sqrt[3]{\frac{8 \sin \theta}{f}} \cos \theta
\end{gathered}
$$

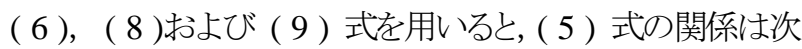
のように変換される.

$$
\begin{array}{r}
C=F\left(\frac{y}{y_{0.9}}, \frac{S}{d_{c}} \sqrt[3]{\frac{8 \sin \theta}{f}} \cos \theta, R_{e},\right. \\
\left.\sqrt{\frac{8 \tan \theta}{f}},\left(\frac{8 \tan \theta}{f}\right)^{\frac{1}{6}} R_{e}^{\frac{2}{3}}, \theta\right)
\end{array}
$$

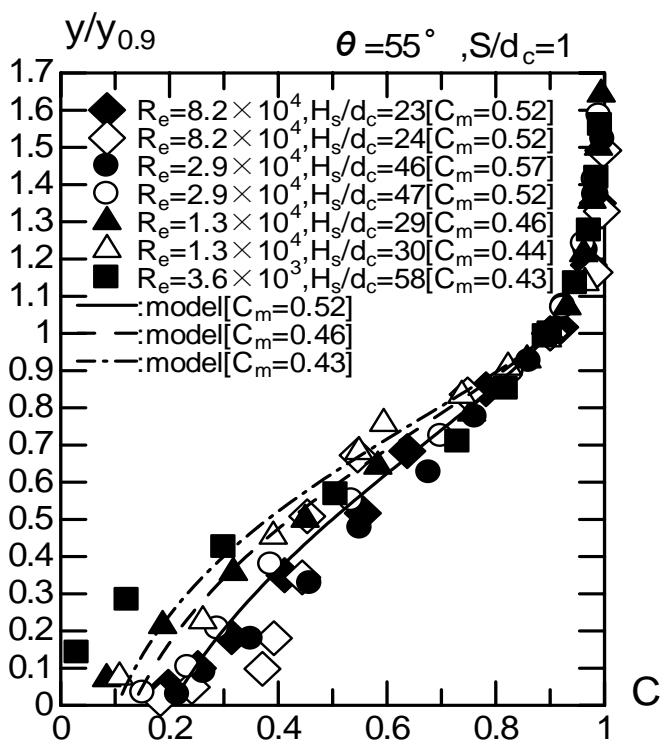

a)

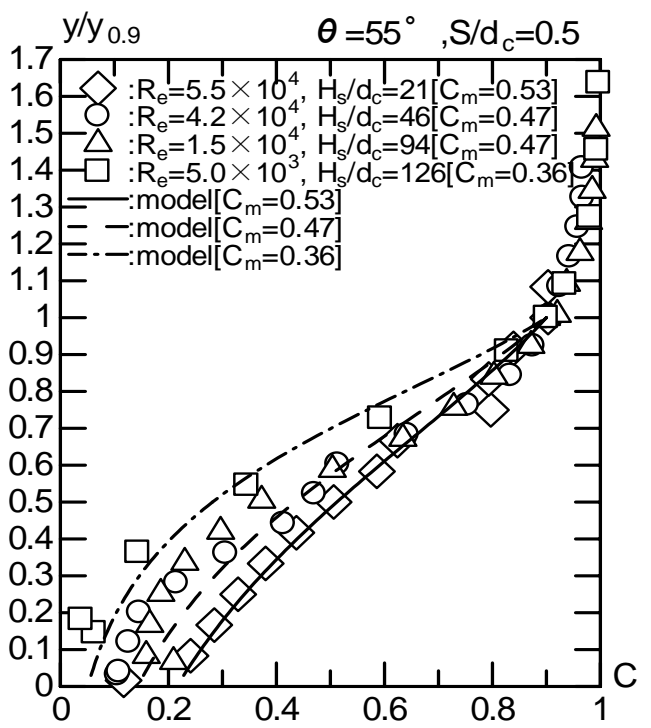

b)

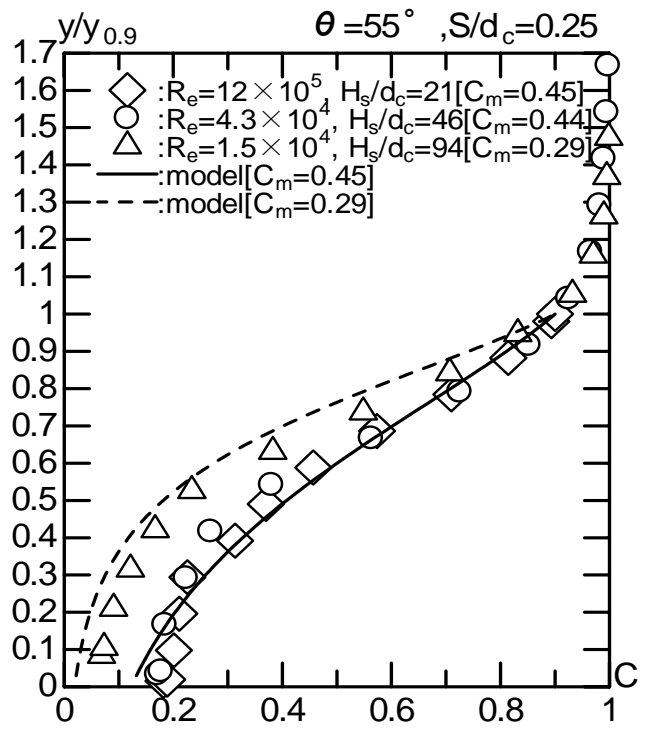

c)

図 - 4 空気混入率分布に対するレイルルズ数の影響 $H_{s}:$ 図 - 2 参照, model:気泡の拡散モデル2) 


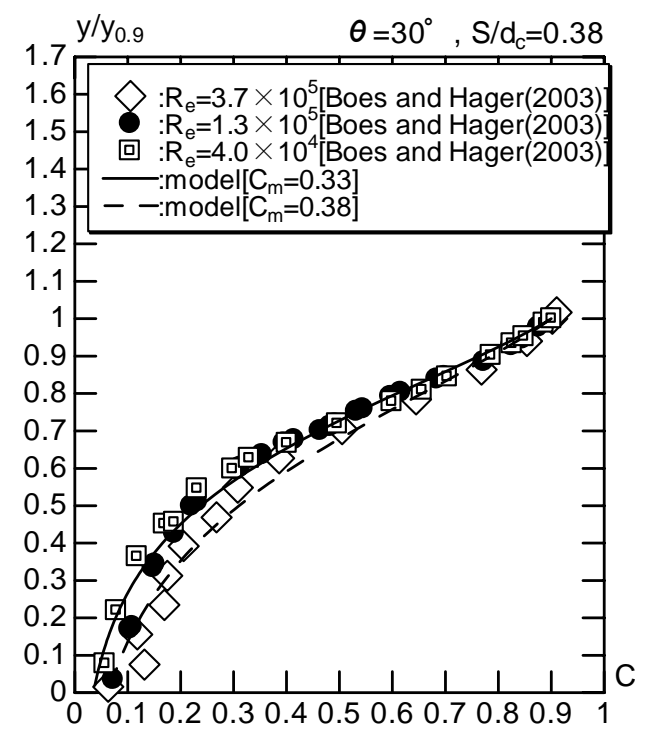

a)

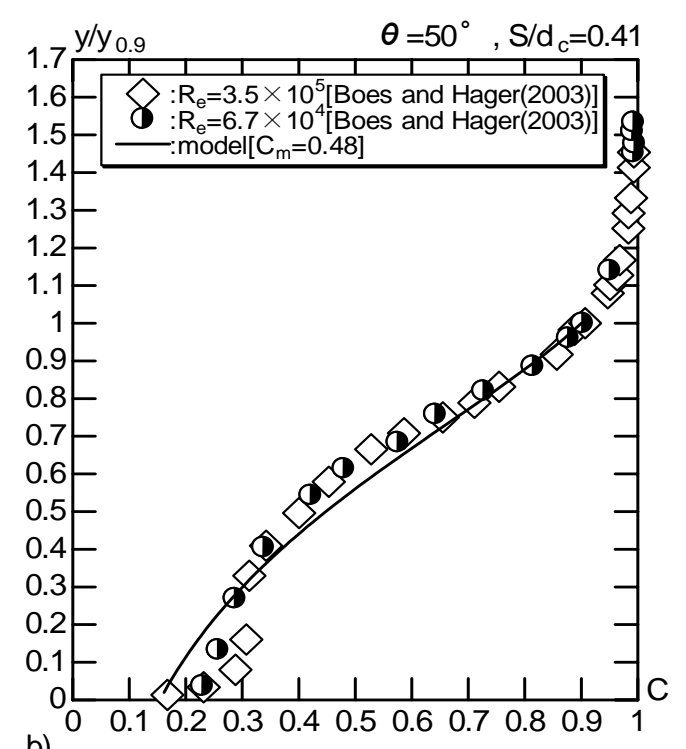

b)

図 - 5 Boes and Hager による空気混入率分布の測定結果

一方, 擬似等流状態の Skimming flowにおける抵抗係数 $f$ は次元解析的考察から一般に次の関係で示されるものと 考えられる

$$
f=F\left(\frac{S \cos \theta}{d}, F_{r}, \theta, R_{e}\right)
$$

$(8),(9)$ 式を用いると, $f$ は次の関係で示される ${ }^{5)}$.

$$
f=\left(\frac{S}{d_{c}}, \theta, R_{e}\right)
$$

(10)式は(12)式の関係を用いると次のように整理される.

$$
C=F\left(\frac{y}{y_{0.9}}, \frac{S}{d_{c}}, R_{e}, \theta\right)
$$

なお, $S / d_{c}$ は $S / d_{c}=V d(g S)^{0.5}$ と表すことができ, Step Froude Number と解釈 5)することもできる.

与えられた水路傾斜角度 $\theta$, 相対ステップ高さ $S / d_{c}$ に 対して空気混入率 $C$ を( 13 )式の関係で整理したものを 図 - 4 に示寸．なお，図中の各線は空気混入率の分布形 状に関して Chanson が提案した気泡の拡散モデル ${ }^{2)}$ に基 づいて描かれている. 図-4に示されるように, 水路傾 斜角度 $\theta=55^{\circ}$ の場合, レイノルズ数 $R_{e}$ が $3.6 \times 10^{3} \leq R_{e}<$ $3.0 \times 10^{4}$ では, 空気混入率 $C$ の分布はレイノルズ数 $R_{e}$ に よって変化する. 特に, レイノルズ数 $R_{e}$ が小さくなるに つれて空気混入率 $C$ が小さくなっている. これは, レイ ノルズ数が小さくなるにつれて, 粘性の影響が大きくな り，かつ乱れ強さが小さくなったために，水面から取込 まれた気泡が仮想底面近くまで到達しにくくなったもの と推論される.

レイノルズ数 $R_{e}$ が $3.0 \times 10^{4} \sim 4.0 \times 10^{4}$ 以上になると, 本 実験範囲ではレイノルズ数 $R_{e}$ の変化による空気混入率 $C$
の分布の変化は認められない.

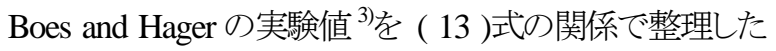
ものを図 - 5 に示寸. 図に示されるように, 空気混入率 $C$ の 測定精度を勘案すると彼らの実験範囲 $\left(4.0 \times 10^{4}<R_{e} \leq\right.$ $\left.3.7 \times 10^{5}\right)$ においては $C$ の分布形状に対寸るレイノルズ数 $R_{e}$ の影響は認められない.

すなおち, (13)式の関係で空気混入率 $C$ の分布を整理し た場合, Boes and Hager の実駼結果 $\left(\theta=30^{\circ}\right.$ および $\left.50^{\circ}\right)$ を含

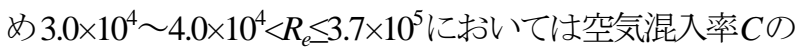
分布に対寸るレイノルズ数 $R_{e}$ の影響が認められない.

\section{4. aerated flow depth $y_{0.9} / d_{c}$ に対するレイノル ズ数 $R_{e}$ の影響}

擬似等流状態の aerated flow depth $y_{0.9} / d_{c}$ に対するレイ ノルズ数 $R_{e}$ の影響を図 - 6(a) に示寸. また, 図 - 6(b)に はBoesによる実験結果 ${ }^{8)}$ を示寸。

図に示されるように, $3.6 \times 10^{3} \leq R_{e}<3.0 \times 10^{4}$ の範囲では, aerated flow depthの無次元量 $y_{0.9} / d_{c}$ はレイノルズ数 $R_{e}$ によ って変化する. すなわち, $R_{e}$ が小さくなると, $y_{0.9} / d_{c}$ の値は 小さくなる. また, $3.0 \times 10^{4} \sim 4.0 \times 10^{4} \leq R_{e} \leq 3.0 \times 10^{5}$ になると, $y_{0.9} / d_{c}$ に対する $R_{e}$ の影響は認められない.

\section{5. 流速分布に対するレイノルズ数 $R_{e}$ の影響}

次元解析的考察功, Skimming flow の擬似等流状態に おける edge section での流下方向の時間平均流速 $\bar{u}$ は次 の関係で示される.

$$
\frac{\bar{u}}{U_{0.9}}=F\left(\frac{y}{y_{0.9}}, \frac{S \cos \theta}{d}, \theta, F_{r}, R_{e}, W_{e}\right)
$$



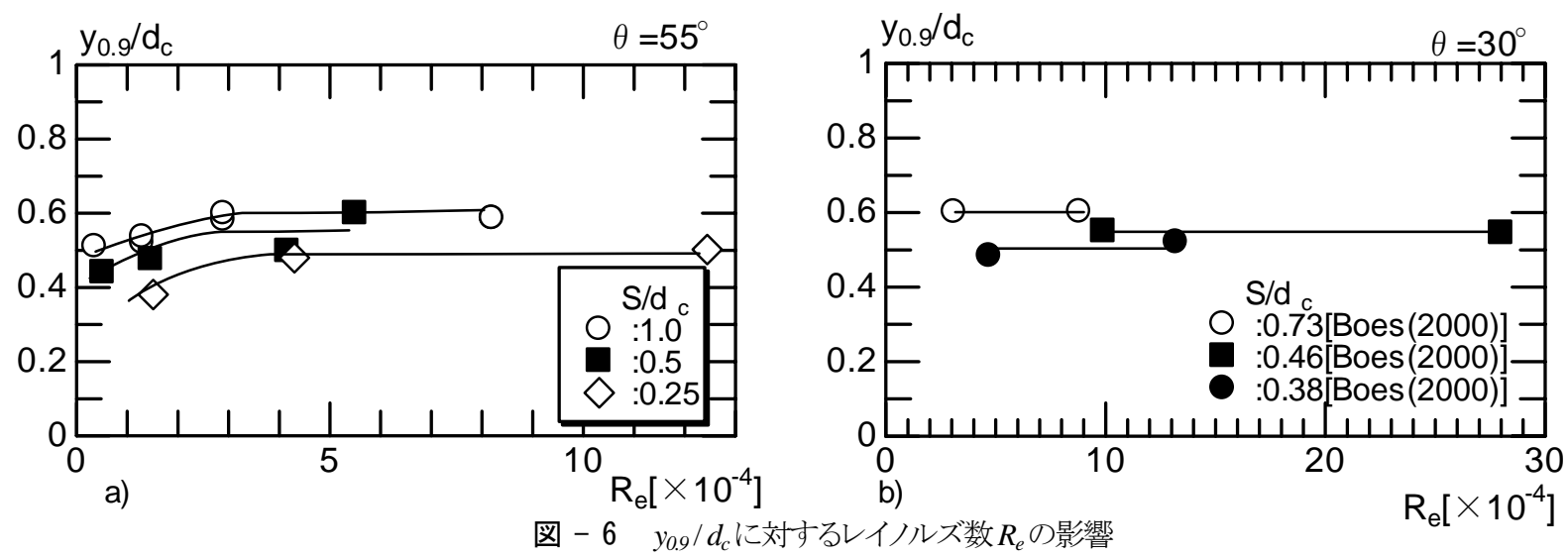

ここに, $U_{0.9}$ は $y=y_{0.9}$ での $\bar{u}$ である.

( 6 ), ( 7 )，（８),および ( 9 )式の関係を用いると( 14 )式の 関係は次のように示される.

$$
\frac{\bar{u}}{U_{0.9}}=F\left(\frac{y}{y_{0.9}}, \frac{S}{d_{c}}, \theta, R_{e}\right)
$$

Skimming flow における流速 $\bar{u}$ について Boes and Hager

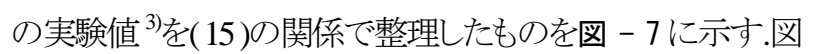
に示されるように, $4.0 \times 10^{4} \leq R_{e} \leq 3.7 \times 10^{5}$ において、 $R_{e}$ の変化 による流速分布の変化はほとんど認められず, 流速分布は $1 / 6$ 乗則で近似される. なお, $30^{\circ} \leq \theta \leq 55^{\circ}$ でかつ $4.0 \times 10^{4} \leq$ $R_{e} \leq 3.7 \times 10^{5}$ では, (15)式の関係で整理された流速分布は $1 / 6$ 乗則によって近似される ${ }^{\circ}$.

\section{6.空気混入射流の平均流速 $V_{a v e}$ に対するレイノル ズ数 $R_{e}$ の影響}

空気混入射流中の aerated flow depth 内の平均流速 $V_{\text {ave }}$ を次のように定義する。

$$
V_{\text {ave }}=\frac{1}{y_{0.9}} \int_{0}^{y_{0.9}} \bar{u} d y
$$

空気混入射流の平均流速 $V_{\text {ave }}$ と水のみに換算された水 深 $d$ から求められる断面平均流速 $V_{w}\left(=q_{w} / d\right)$ との比は $y^{+}=y / y_{0.9}$ および $u^{+}=\bar{u} / U_{0.9}$ を用いると次式で示される ${ }^{0}$.

$$
\frac{V_{\text {ave }}}{V_{w}}=\frac{\left(1-\int_{0}^{1} C d y^{+}\right) \int_{0}^{1} u^{+} d y^{+}}{\int_{0}^{1}(1-C) u^{+} d y^{+}}
$$

(17)式より, $V_{a v e} / V_{w}$ の值は aerated flow depth $y_{0.9}$ 内の流速 $u^{+}$および空気混入率 $C$ の分布形状から求められる.

$4.0 \times 10^{4} \leq R_{e} \leq 3.7 \times 10^{5}$ において空気混入率分布および流 速分布に対寸る $R_{e}$ の影響が認められないことから, $V_{a v e} / V_{w}$ に対する $R_{e}$ の影響も $4.0 \times 10^{4} \leq R_{e} \leq 3.7 \times 10^{5}$ については認めら れない.

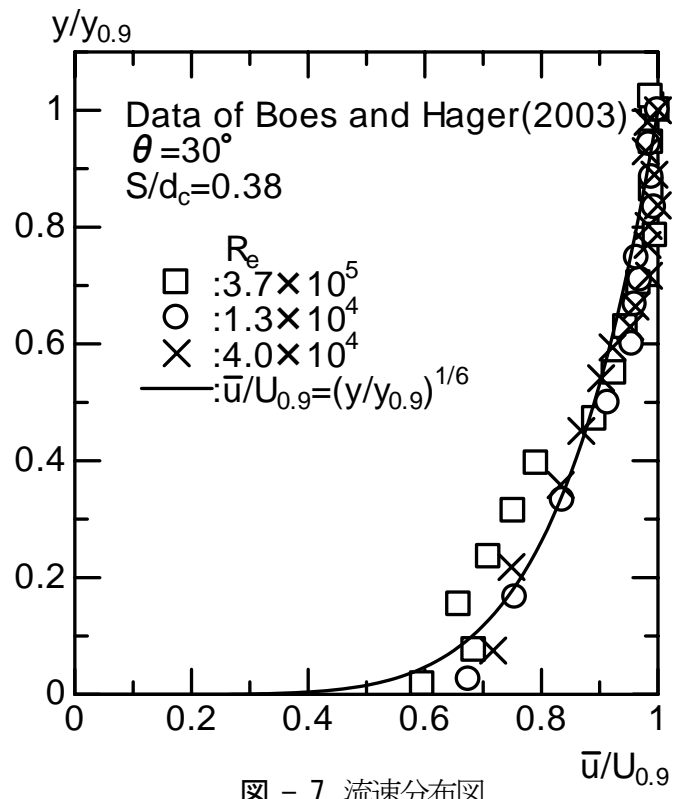

なお, 著者らは $30^{\circ} \leq \theta \leq 55^{\circ}$ の Skimming flow を対象に, 空気混入率の分布形状を気泡の拡散モデルを用い, 流速 分布は $1 / 6$ 乗則で近似することによって, $V_{a x e}$ が $V_{w}$ とほぼ等 しい值 $\left.V_{\text {ave }}=(1.02 \sim 1.09) V_{w}\right]$ になることを示しているの.

\section{Skimming flow におけるフルードの相似則の適用範囲}

階段状水路の水工設計において, 与えられた水路幅 $B$, 落 差 $H_{d a n}$, 水路傾斜角度 $\theta$ および水のみの流量 $Q_{w}$ に対して, Skimming flow が形成されるステップ高さ $S$ を設定したとき, 階 段状水路終端での流速, 水深がごの程度の大きさになるのか を推定する必要がある。

Skimming flow $の$ 抵抗係数 $f$ およ゙ aerated flow の流速分布 に対してレイルルズ数 $R_{e}$ の影響を無視できる場合にフルード の相似則老適用できる。

抵抗係数 $f$ にいては( 7 )式より次のように変換すること ができる. 


$$
\begin{gathered}
f=\frac{4 \tau_{0}}{\frac{1}{2} \rho_{w} V_{w}{ }^{2}}=\frac{8 \int_{0}^{y_{0.9}} \rho g d y \sin \theta}{\rho_{w}\left(q_{w} / d\right)^{2}} \\
=8\left(\frac{y_{0.9}}{d_{c}} \int_{0}^{1}(1-C) d y^{+}\right)^{3} \sin \theta
\end{gathered}
$$

$R_{e} \geqq 3.0 \times 10^{4} \sim 4.0 \times 10^{4}$ の場合, 空気混入率 $C$ の分布およ び相対 aerated flow depth $y_{0.9} / d_{c}$ に対して $R_{e}$ の影響が認めら れない(3，4 章参照)ことから，(18)式より $f$ に対する $R_{e}$ の影 響も認められない. $f$ に対する $R_{e}$ の影響が認められない場 合には, (7)式より $d / d_{c}$ に対寸る $R_{e}$ の影響も認められない. また, $d / d_{c}=V_{d} / V_{w}$ であることから, $V_{d} / V_{w}$ に対する $R_{e}$ の影響も 認められない. ここに, $V_{c}$ は限界流速である $\left(V_{c}=q_{w} / d_{c}\right)$. なお, $R_{e} \geqq 4.0 \times 10^{4}$ の場合に $R_{e}$ の影響を受けない $V_{a v e} / V_{w}$ の值を知ることができる. すなわち, 抵抗係数 $f$ と単位幅流 量 $q_{w}$ から $d, V_{w}$ および $V_{c}$ を算定し， $V_{\text {ave }} N_{w}$ の值力ら $V_{\text {ave }}$ を求め, フルードの相似則を用いて原型の $d, y_{0.9}, V_{w}, V_{\text {ave }}$ が得られる。

著者らは最近, Skimming flowの流況区分, 擬似等流状態 が形成されるための水理条件, 擬似等流状態における抵抗 係数, 擬似等流区間と不等流区間のエネルギーおよび断面 平均された空気混入率 $C_{m}$ を実験的に明らかにした ${ }^{5}$. また, $V_{a v e} / V_{w}$ の值を明確に示したの $)$.これらの結果は $R_{e} \geq 3.0 \times 10^{4} \sim$ $4.0 \times 10^{4}$ の実験に基づいて得られていることから, フルードの 相似則に基づき, 原型の水のみに換算された水深 $d$, aerated flow depth $y_{0.9}$, および空気混入射流の平均流戈 $V_{a v e}$ が予測 できる.

レイノルズ数 $R_{e}\left(=q_{w} / v_{w}\right)$ が $R_{e}<3.0 \times 10^{4}$ の場合, Skimming flow の空気混入率分布および aerated flow depth に対するレイノルズ数の影響が無視できない. 景観に配慮 して, 階段状水路を用いた流水美デザインを行う場合, $R_{e}$ が 3.0×10 $0^{4}$ 以下となる場合もある.このような場合, レイル ズ数が小さくなるにつれて, white water の状態から徐々に 透明感のある流れへと変化する.このような流れの流況特 性を知り, 流水美デザインに用いるためには模型と原型と を同寸法にした水理実験が必要である.

\section{8.まとめ}

階段状水路における Skimming flow の空気混入率分布, aerated flow depth, および流速分布に対するレイノルズ数 $R_{e}$ の影響こつ いて検执た. 得られた結果を以下に要的して述いる.

(1) 擬似等流状態における空気混入率 $C$ は $C=\mathrm{F}\left(y / y_{0.9}\right.$, $\left.S / d_{c}, R_{e}, \theta\right)$ の関係で表示されることを明らかにした.

(2) 擬似等流状態の Skimming flow $の$ 空気混入率 $C$ の分布 は $R_{e}<3 \times 10^{4}$ の範囲ではレイノルズ数 $R_{e}$ によって変化す ることを示した(図 - 4). また, $3.0 \times 10^{4} \sim 4.0 \times 10^{4} \leq R_{e} \leq$ $3.7 \times 10^{5}$ の範囲では空気混入率 $C$ の分布に対する $R_{e}$ の
影響が無視できることを明らかにした（図－4, 図 - 5)。

(3) 擬似等流状態の aerated flow depth $y_{0.9} / d_{c}$ に対寸るレイ ノルズ数 $R_{e}$ の影響について示した. すなわち, $R_{e}<3.0 \times 10^{4}$ の範囲では, $R_{e}$ が小さくなると, $y_{0.9} / d_{c}$ は小 さくなり, $R_{e} \geq 3.0 \times 10^{4} \sim 4.0 \times 10^{4}$ になると, $y_{0.9} / d_{c}$ に対寸 る $R_{e}$ の影響が無視できることを示した (図 - 6).

(4) 擬似等流状態における aerated flow の流下方向の流速 分布について, Boes and Hagerの実験值を用いて(15) の関係で整理すると, $4.0 \times 10^{4} \leq R_{e} \leq 3.7 \times 10^{5}$ の範囲では $\bar{u} / U_{0.9}$ に対寸るレイノルズ数の影響は認められないこと を示した(図 - 7)。

(5) 空気混入射流の平均流速 $V_{\text {ave }}$ と水に換算した水深力ら 求められる断面平均流速 $V_{w}$ の比 $V_{\text {ave }} / V_{w}$ が( 17$)$ 式 で示され， $V_{\text {ave }} / V_{w}$ に対する $R_{e}$ の影響は $4.0 \times 10^{4} \leq R_{e}$ $\leq 3.7 \times 10^{5}$ では認められないことを説明した.

(6) 階段状水路流れにおいて $R_{e}\left(R_{e}=q_{w} / v_{w}\right) \geqslant 3.0 \times 10^{4}$ $\sim 4.0 \times 10^{4}$ の実験結果はフルードの相似則を満足する ことを説明した. また, 流量規模が小さ $<R_{e}<3.0 \times 10^{4} \sim$ $4.0 \times 10^{4}$ の場合, 水工設計に必要な水深・流速を得るた めには原型と模型とが同寸法の水理模型実験が必要 であることを説明した。

\section{参考文献}

1) Ohtsu, I., and Yasuda, Y.: "Characteristics of Flow Conditions on Stepped Channels.", Proc. of the $27^{\text {th }}$ Cong. $I A H R$, Theme D, Water for a Changing Global Community, San Francisco, USA, pp.583-588, 1997.

2) Chanson, H.: The Hydraulics of stepped chutes and spillways, Balkema, Lisse, 2001.

3) Boes, R.M., and Hager, W.H.: "Two-Phaseflow Characteristics of Stepped Spillways.", J. Hydr. Engrg., ASCE, Vol.129, No.9, pp.661-670, 2003.

4) Boes, R.M.: Discussion of "Characteristics of Skimming Flow over Stepped Spillways.", J. Hydr. Engrg., ASCE, Vol.125, No.4, pp.860-862, 2000.

5) Ohtsu, I., Yasuda, Y., and Takahashi, M.: "Flow Characteristics of Skimming Flows in Stepped Channels.", J. Hydr. Engrg., ASCE, Vol.130, No.9, pp.860-869, 2004.

6) Ohtsu, I., Yasuda, Y., and Takahashi, M.:'Energy Head of Aerated Flows in Stepped Channels.", Proc. of the 31th Cong. IAHR, Theme D, IAHR, Seoul, Korea, pp.2890-2899, 2005.

7) Wood, I. R.: Air Entrainment in Free-Surface Flows, Balkema, Rotterdam, 1991.

8) Boes, R.M. : Zweiphasenströmung und Energieumsetzung auf Grosskaskaden, Ph.D thesis, ETH, Zürich, Switzerland, 2000. (In German.)

(2005. 9. 30. 受付) 